\title{
光学活性カルコゲヌランの合成, 反応とその立体化学
}

\author{
張健***・黒 瀬 規 之*・斎 藤 慎 -* \\ 高 橋 たみ子*・小 泉徹*
}

\section{Optically Pure Chalcogenuranes:Synthesis and Stereochemical Research of Their Reactions}

\author{
Jian ZhANG ${ }^{* * *}$, Noriyuki Kurose*, Shinichi SaIto* \\ Tamiko TAKAHASHI* and Toru Koizumi*
}

\begin{abstract}
An overview of the recent studies on the asymmetric syntheses, stereochemical studies, reactions and applications of chiral chalcogenuranes is described. Chiral chalcogenuranes, including halooxachalcogenuranes and spirochalcogenuranes, have been synthesized by highly diastereoselective oxidation of the 2-exo-hydroxy-10-bornyl chalcogenides. The stereochemistry of chalcogenuranes have been confirmed to be trigonal bipyramid (TBP). Nucleophilic reactions of these compounds provided a good method to prepare the chiral chalcogenonium (IV) compounds with excellent diastereoselectivity . Hydrolysis of the chiral spirosulfurane gave optically pure sulfoxides with different stereochemistry at the sulfur atom under various conditions, which indicated that the reactivity of the axial bonds plays an important role in the control of the stereochemistry of the reactions. Mechanistic and stereochemical studies on the nucleophilic reactions have revealed that two kinds of pathways, dissociative and associative routes, seem to exist. The application of the reactions through the $[2,3]$ sigmatropic rearrangment and enantioselective protonation with optically active selenonium compounds have been investigated to give good selectivities of the reactions.
\end{abstract}

Key words : Asymmetric synthesis, Stereochemistry, Reaction, Application, Chiral chalcogenurane, Chiral chalcogenonium (IV) compound

\section{はじめに}

有機合成上有用な化合物である有機カルコゲニウム (IV)化合物についての研究は幅広く行われている。その 中であ不斉合成によく使われている光学活性硫黄化合物 の合成と反応についての研究は数多く報告されてい

* 富山医科薬科大学薬学部薬化学

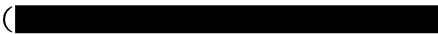

** 現所属：東京大学大学院総合文化研究科生命環境科 学系

* Faculty of Pharmaceutical Sciences, Toyama Medical \& Pharmaceutical University

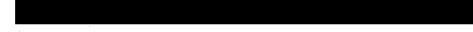

** Present address : Department of Life Sciences, Graduate School of Arts and Sciences, The University of Tokyo,

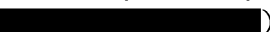

る1。当研究室においても，硫黄原子のキラリティーを 利用しキラルスルフィニルエテン類の不斉ディールス． アルダー反応を行い, 高い選択性で付加環加体を得るこ とに成功した ${ }^{2)}$ 。また, 最近, 同族である光学活性セレン やテルル化合物の合成と応用についても目覚ましい進歩 が見られている3,4)。光学活性有機カルコゲニウム (IV)化 合物には図 1 に示すように光学活性カルコゲノキシド 1a，カルコゲノニウムイミド $1 \mathrm{~b}$ ，カルコゲノニウムイ リド 1c，カルコゲノニウム塩 $1 \mathrm{~d}$ 等が考えられる。しか し，光学活性有機カルコゲニウム化合物の一般的な合成 法はまだ確立していない，その原因の 1 つとして，反応 の中間体の反応性および立体化学に関する理解がまだ不 十分であることが考えられる。

超原子価化合物である有機カルコゲヌラン 2 が有機カ ルコゲニウム化合物を用いた反応における重要な中間体 として知られている5)。一般的に，カルコゲヌランとは 4 


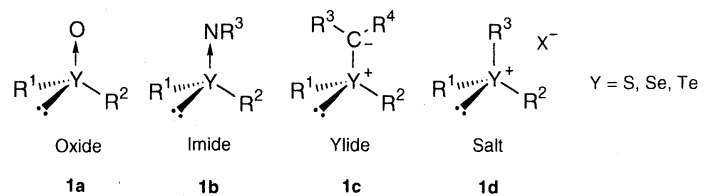

Fig. 1

価 16 族有機化合物であり，カルコゲニウム原子に 5 個 の置換基(孤立電子対を 1 つの置換基とする)が結合した 擬三方両錐構造をとっており, カルコゲニウム原子に異 なる置換基が結合すればキラリティーを持つことができ る。また, 置換基によって, 非環状, 単環状または双環 状等の構造をもつカルコゲヌラン化合物がある。代表的 な例として図 2 に示すハロカルコゲヌラン $2 \mathrm{a}$, 八ロオ キサカルコゲヌラン $2 b$ およびスピロカルコゲヌラン $2 c$ が報告されている ${ }^{6)}$ 。

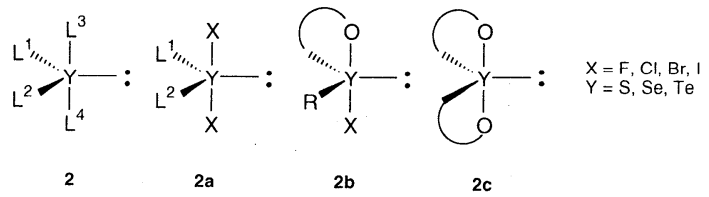

Fig. 2

一方, 四配位型構造を有する化合物の求核反応は炭素 原子を中心として数多く報告された， $\mathrm{S}_{\mathrm{N}} 1$ や $\mathrm{S}_{\mathrm{N}} 2$ のよう な反応は有機反応の基本反応として知られている。これ と比べて, 五配位型構造をあつ化合物の求核反応につい ての研究はまだ不十分であると考えられる7)。最近, 我々は 2-エキソーヒドロキシー10-ボルニル基をキラルリ ガンドとした光学活性カルコゲヌランの合成に成功し, またその求核反応の立体化学についての研究を行った。 以下にまとめて紹介する。

\section{1. 光学活性カルコゲヌランの合成とその立体化学}

\section{1. 光学活性ハロカルコゲヌランの合成とその立体化学}

1.1.1. 光学活性ハロカルコゲヌランの合成とその立体 化学

アキラルなカルコゲヌランは 60 年代から Martin ら を中心に研究されだ)。しかし，光学活性なカルコゲヌ ランについての研究例は極めて少ない。キラルハロカル コゲヌランの初めての合成例は 1975 年に Martin らの キラルクロロスルフラン 3 である8 ${ }^{8)}$ スキーム 1 に示す ように光学活性なスルホキシドを用い塩化アセチルと反 応させたところキラルクロロスルフラン 3 の合成に成功
した。3 の光学純度をシフト試薬を用いて NMR で確認 し, ee は 95\%であることが分かったが, その絶対構造は 明らかにされていない。その後約 30 数年間, 光学活性力 ルコゲヌランの研究の進展はほとんど見られなかった。

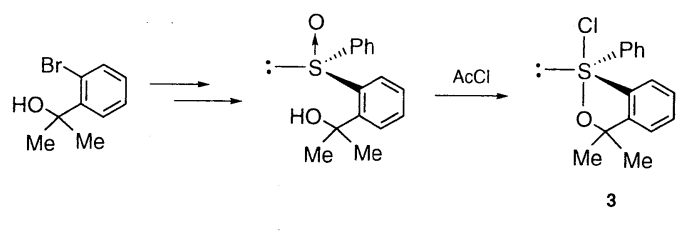

Scheme 1

また，大饗らはスキーム 2 に示すようなキラルアル コールを不斉リガンドとして利用し, 非環状キラルクロ ロスルフラン 4 を経て光学活性硫黄化合物の合成を報告 したが，その中間体であるキラルクロロスルフラン 4 の 立体化学については詳しい研究はなされなかった吕。ま た, 最近この方法を利用した光学活性スルホキシドの合 成を報告している ${ }^{9 \mathrm{~b})}$ 。

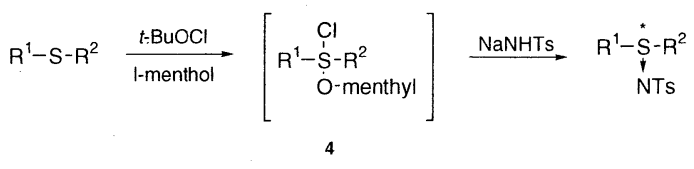

Scheme 2

光学活性カルコゲヌランの合成法としては 2 つ方法が 考えられる。1つは非光学活性なカルコゲン化合物から 不斉反応によって合成する方法である, あう 1 つは光学 活性なキラルリガンドを用いて光学誘導することによ り，カルコゲン原子上に不斉中心を構築する方法であ る。我々は後者の方法を利用し, 以下の理由から, 2-エ キソーヒドロキシー10-ボルニル基を不斉リガンドとして 選択した。1)原料が安価であること，2)両エナンチオ マーが合成できる，3)ボルニル基のかさ高さおよび 5 員 環効果 ${ }^{6}$ によって生成するカルコゲヌランは安定化され る，4)結晶性が良いため, その構造は X 線結晶解析に よって確認しやすい，5)ボルニル基をむつカルコゲン化 合物は不斉反応に非常に有用 ${ }^{10)}$ 等の利点がある。

そこで我々はまず, 原料である光学活性カルコゲニド の合成を行った(スキーム3)。市販されている(+)-10カンファースルホン酸からハロカンファーまたはジボル ニルジカルコゲニドを経てアルキルおよび芳香族の光学 活性カルコゲニド 5-7を容易に合成できた。

光学活性スルフィド 5 と次亜塩素酸 tert-ブチルを反 


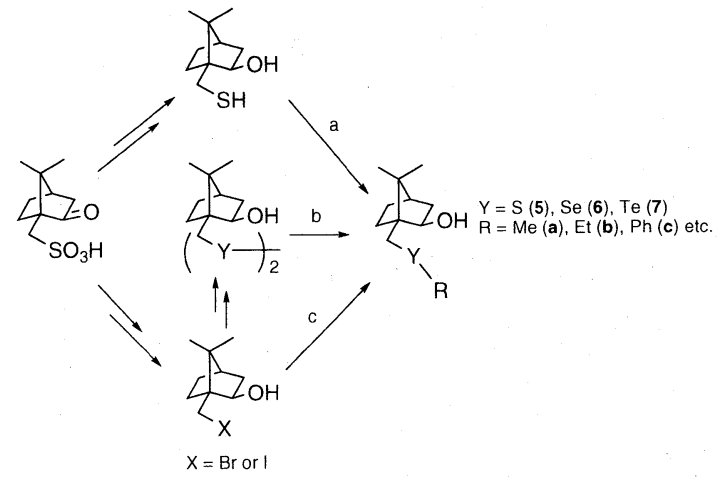

Scheme 3

応させたところ, 光学活性クロロスルフラン 8-Clを高 收率で単一ジアステレオマーとして得ることができた （スキーム 4)。得られたクロロスルフランは水に対して 不安定だが，その構造を NMR 等のスペクトルによって 決定した ${ }^{11)}$ 。一方, 同様な方法によって高選択的高収率 で合成した光学活性クロロセレンヌラン 9-Cl ${ }^{12)}$ やテル ラン $10-\mathrm{Cl}{ }^{13)}$ は室温数か月放置してあ分解せず, 安定な 化合物であることが分かった。また，我々はカルコゲニ ドの還元性および親八ロゲン性を利用し, 活性ハロゲン 化合物との脱ハロゲン化反応によるハロオキサテルラン の合成法を開発した ${ }^{14)}$ 。

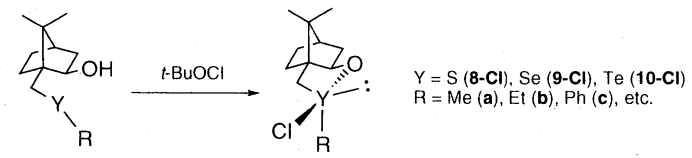

Scheme 4

セレンヌランやテルランの X 線結晶解析の結果から, 光学活性カルコゲヌランは三方両鍾型構造をとってお り，カルコゲン原子上の絶対構造についてあ明らかにし た ${ }^{12,13)}$ 。キラルカルコゲニドからカルコゲヌランへの生 成反応はいずれも高ジアステレオ選択的に進行してお り，スキーム5 のように説明できる。すなわち，カルコ ゲニドが酸化され， $\mathrm{A}\left(\mathrm{A}^{\prime}\right)$ のようなカルコゲノニウムカ チオンとなった後, 分子内の水酸基と 5 員環を形成し, カルコゲヌランを与えるというあのである。 5 員環を形 成した際, 酸素原子や塩素原子は電子求引基であるた め, カルコゲヌランのアピカル位を占めることで安定化 する。すなわち，この反応から考えられる生成物がス キーム 5 に示すような B と $\mathrm{B}^{\prime} 2$ 種類しかない。また， B のジアステレオマーである $\mathrm{B}^{\prime}$ は立体上の原因で熱力的
により不安定なため, この反応は高ジアステレオ選択的 に進行し,カルコゲヌラン B が得られると考えられる。

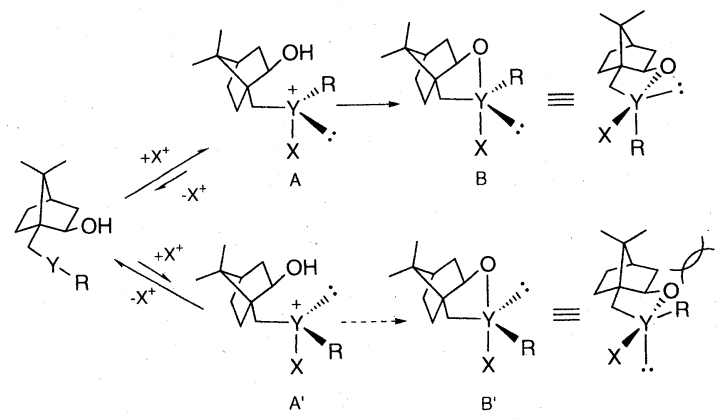

Scheme 5

以上の結果から，適当なかさ高さおよび適切な位置に 水酸基を持つ不斉リガンドから高ジアステレオ選択的に 光学活性ハロオキサカルコゲヌランを合成できることが 分かった。

\subsection{2. 光学活性ハロカルコゲヌランの NMR スペクト ルの特性}

Martin らは，アキラルなスルフランの NMR スペク トルを検討した結果, スルフランの構造の特性は ${ }^{1} \mathrm{H} や$ ${ }^{13} \mathrm{C}$ NMR 等のスペクトルに反映されている。特に,アピ カル位のアルキル炭素およびこの炭素と結合してる水素 の化学シフトはスルフランの両アピカル結合の分極を示 唆している15)。

そこで，我々は同じ構造を有するハロカルコゲヌラン

Table $1{ }^{1} \mathrm{H}$ NMR and ${ }^{13} \mathrm{C}$ NMR chemical shifts of chlorosulfuranes, selenuranes and telluranes.

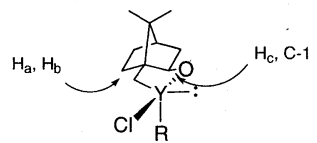

\begin{tabular}{cccccccc}
\hline entry & compound & $\mathrm{Y}$ & $\mathrm{R}$ & $\mathrm{Ha}$ & $\mathrm{Hb}$ & $\mathrm{Hc}$ & $\mathrm{C}-1$ \\
\hline 1 & $\mathbf{8 c - C l}$ & $\mathrm{S}$ & $\mathrm{Ph}$ & 4.57 & 4.69 & 4.34 & 100.4 \\
2 & $\mathbf{9 c - C l}$ & $\mathrm{Se}$ & $\mathrm{Ph}$ & 4.15 & 4.32 & 3.97 & 96.3 \\
3 & $\mathbf{1 0 c - C l}$ & $\mathrm{Te}$ & $\mathrm{Ph}$ & 3.42 & 3.62 & 3.81 & 93.2 \\
4 & $\mathbf{8 a - C l}$ & $\mathrm{S}$ & $\mathrm{Me}$ & 4.13 & 4.52 & 4.88 & 101.6 \\
5 & $\mathbf{9 a - C l}$ & $\mathrm{Se}$ & $\mathrm{Me}$ & 3.84 & 4.23 & 4.49 & 96.8 \\
& & & & & & & \\
6 & $\mathbf{1 0 a - C l}$ & $\mathrm{Te}$ & $\mathrm{Me}$ & 3.40 & 3.59 & 4.19 & 93.7 \\
\hline
\end{tabular}


の ${ }^{1} \mathrm{H}$ および ${ }^{13} \mathrm{C}$ NMR の化学シフトを比較したところ, カルコゲン原子の隣のメチレンまたは酸素の隣のプロト ンおよび炭素原子の化学シフトは $\mathrm{S}, \mathrm{Se}, \mathrm{Te}$ の順番で高 磁場シフトしていることが明らかとなった。また，フェ ニルの場合と比べて, メチルカルコゲヌランの $\mathrm{Ha}, \mathrm{b}$ の ${ }^{1} \mathrm{H}$ NMR 化学シフト值はより小さく, Hc はより大きい ことが観察された（表 1)。

\section{2. 光学活性スピロカルコゲヌランの合成とその立体 化学}

アキラルなスピロカルコゲヌランの合成についても

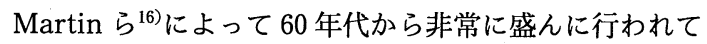
いたが, 光学活性なスピロカルコゲヌランの合成はこれ までに例が少ない。

1972 年, Lindgren らは 11 のような光学活性スピロ セレヌランを光学分割によって単離することに成功し た ${ }^{17)}$ 。1978 年, Kavopits らは光学分割法によって得ら

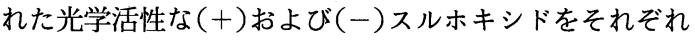
出発物質として DMF 中低温で, $\mathrm{AcCl}-\mathrm{Et}_{3} \mathrm{~N}$ と反応させ ることにより, 対応する $(+),(-)$ 光学活性なスピロス ルフラン 12a の合成に成功した ${ }^{18 a)}$ 。

また最近, Szabó らはこの方法を利用し, スピロスル フラン $(+)-12 \mathrm{a}, \quad(+)-12 \mathrm{~g}$ および $(+),(-)-12 \mathrm{~h}$ を合 成し，その絶対配置を(+)-12a および $(+)-12 h$ の X 線 構造解析によって決定した (図 3) ${ }^{18 \mathrm{e})}$ 。
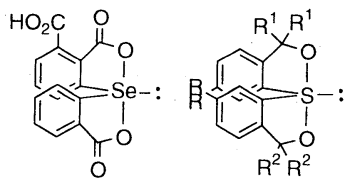

12a: $R=H, R^{1}=H, R^{2}, R^{2}=O$

11 12b: $R=H, R^{1}, R^{1}=R^{2}, R^{2}=O$ 12c: $R=H, R^{1}=R^{2}=M e$ 12d: $\mathrm{R}=t-\mathrm{Bu}, \mathrm{R}^{1}=\mathrm{R}^{2}=\mathrm{CF}_{3}$

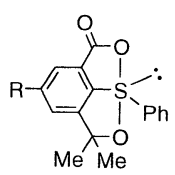

12e, $\mathrm{R}=\mathrm{H}$ 12f, $R=t-B u$

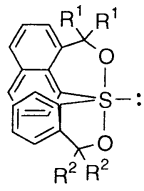

12g: $R^{1}=H$ $R^{2} \cdot R^{2}=0$

12h: $R^{1}, R^{1}=0$ $R^{2}=H$
Fig.3

また, 1993 年, Allenmark らはラセミ体であるスピ ロスルフラン $12 b$ に対しキラルクロマトグラフィーを 用いて光学分離により光学活性な $(+),(-)-12 b$ の単 離に成功した ${ }^{18 b)}$ 。1996 年にMartin らはキラル有機酸 を用いて脱水反応を経てスルホキシドから光学活性スピ ロスルフラン 12c,12d を得ることができた ${ }^{12)}$ 。また, 彼 らは図 4 に示すようにスピロスルフラン 12e,f と光学活 性 BINAP との guest-host 作用による kinetic 光学分 割を試みたところ, (+)-12e を得ることができた ${ }^{18 \mathrm{c}, \mathrm{d}) 。}$ しかし，以上の合成は Szabó ら ${ }^{18 \mathrm{e})}$ の報告例を除いて， 收率が低く, 生成したスピロカルコゲヌランの絶対構造

は決めていないので, 立体化学等の情報は全く得られて いない。そこで, 我々は前述の 2-エキソーヒドロキシ-10ボルニル基を不斉リガンドとしたカルコゲニドからハロ オキサカルコゲヌランへの生成反応の高選択性を利用 し, 同じ不斉リガンドをあつ光学活性スピロカルコゲヌ ランの合成を行った。

スルフィド 13a-e を用いて, $0{ }^{\circ} \mathrm{C}$ 無水ジクロロメタン 中, 1.1 当量の次亜塩素酸 tert-ブチルと反応させた後, トリエチルアミン (1.2 当量) と反応させると, 光学活性 スピロスルフラン 14a-e を高收率で単一ジアステレオ

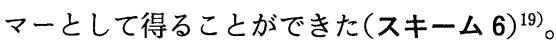

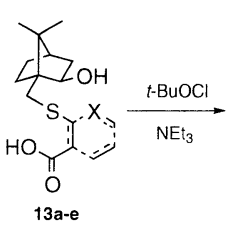

14a および 14b の X 線結晶解析の結果から, スピロス ルフラン 14 は擬三方両錘構造をとっており, それらの 立体化学についても明らかにした。X線データから見る と, 14a，b は以前報告された化合物スピロアシルオキシ アルコキシスルフランと同じく, S-O(アシルオキシ)結 合の長さが S-O (アルコキシ)結合より長いことが分 かった ${ }^{20)}$ 。この構造上の差異がスピロスルフランの反応 性および立体化学に対して影響を与えることが期待され る。

さらに, 我々はスピロスルフランの合成手法と同様に 2-エキソーヒドロキシ-10-ボルニル基を不斉リガンドと した光学活性スピロセレヌランやスピロテルランの合成 にも成功した ${ }^{21)}$ 。

\section{2. 光学活性カルコゲヌランの求核置換反応とそ の立体化学}

\section{1. 光学活性ハロカルコゲヌランの求核置換反応とそ の立体化学}

\subsection{1. 光学活性クロロスルフランの求核反応とその立 体化学}

五配位型化合物の置換反応がぞのような立体化学で進 むのか, また, 四配位炭素化合物の場合の $\mathrm{S}_{\mathrm{N}} 1$ 機構や $\mathrm{S}_{\mathrm{N}} 2$ 機構に対応する dissociative, associative な機構は あり得るのか等はほとんど解明されていない22)。また, 五配位型八ロカルコゲヌラン化合物から四配位カルコゲ ン(IV)化合物への反応の立体化学について説明はまだ明 
らかにされていない, 我々はまず図 4 に示すような提案 をした ${ }^{23)}$ 。すなわち，Cのような立体化学をあつ光学活 性ハロカルコゲヌランからDのような立体化学をあつ 光学活性カルコゲン (IV)化合物への反応は立体保持, ま た逆にCから $\mathrm{E} へ の$ 生成反応は立体反転と提案した。

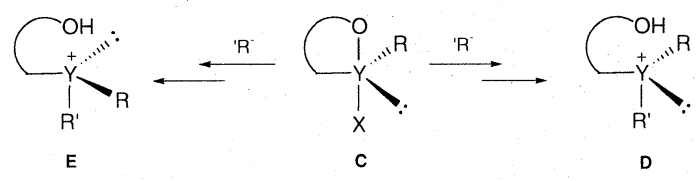

Fig. 4

Martin らはキラルクロロスルフランの加水分解反応 の立体化学等の結果から，スキーム7に示すような六配 位の硫黄化合物を経由する associative な機構を提出し た。しかし, スルフラン 3 の立体化学が不明であるため, その証拠としては不十分と考えられる8

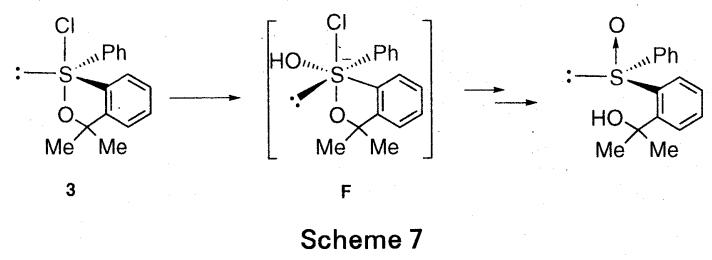

我々は，ここで得られたカルコゲヌラン化合物の求核 置換反応により各種のキラルカルコゲン(IV)化合物を合 成する方法を確立するとともに，その立体化学を明らか にしようと考元た。光学活性クロロスルフラン 8-Clの 求核反応を行った結果， 8-Clをアルカリ加水分解または NaHTs とを反応させたところ，スルホキシド 15，スル フォイミン 16 を立体保持で高收率高選択的に得ること ができた。またクロロスルフランを $\mathrm{NaCH}\left(\mathrm{CO}_{2} \mathrm{Me}\right)_{2}$ と 反応させることによりスルフォニウムイリド 17 を高收 率でジアステレオマー混合物として得た（スキーム 8)。 得られた光学活性スルホキシドおよびスルフォイミンの 立体化学は X 線結晶構造解析によって確認した ${ }^{11,24)}$ 。

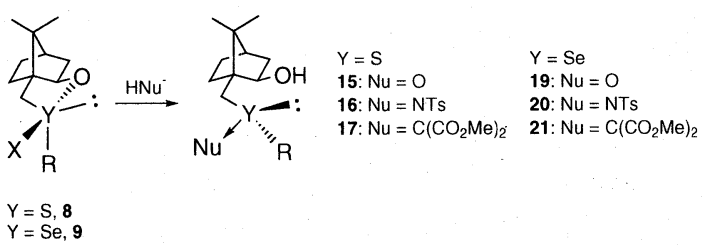

Scheme 8
立体化学の結果から, 我々はこれらの反応では associativeではなく dissociative な機構，すなわち，スル フォニウムカチオンを中間体として経由する反応である と考えている(スキーム 9 ${ }^{11)}$ 。これを証明するために, 重要な中間体と思われるスルフォニウムカチオンの単離 にも成功した。すなわち, クロロフィニルスルフランと $\mathrm{AgBF}_{4}$ とを反応させることにより，スルフォニウムカ チオン 18 を単離することができた。その構造は X 線結 晶構造解析によって確認した(図 5)。このカチオンを用 いてクロロフィニルスルフラン $8 \mathrm{c}-\mathrm{Cl}$ と同じ条件で加水 分解した結果, スルホキシド $15 \mathrm{c}$ をぼ定量的に得られ $た^{24)}$ 。

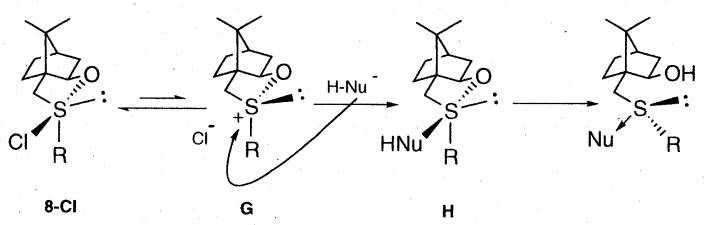

Scheme 9

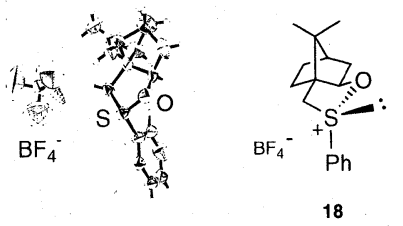

Fig. $5 \quad \mathrm{X}$-ray of 18 .

\subsection{2. 光学活性ハロセレヌランの求核反応とその立体 化学}

光学活性セレン (IV)化合物は光学的に不安定であるた め,これまでにその光学活性体の報告例があるあのの, その光学純度は非常に低いかあるいは未知であり，また その立体化学む全く分かっていない25a,b)。ごく最近, 上 方らは光学分割により光学活性セレン(IV)化合物を単離

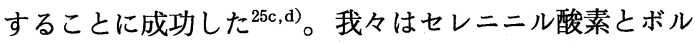
ニル基の水酸基との水素結合により，2-エキソーヒドロ キシー10-ボルニル基を不斉リガンドとした光学活性セレ ン(IV)化合物を合成できると考え, 光学活性ハロセレヌ ランと求核試薬との反応を行った (スキーム 8)。そその結 果, 光学活性セレノキシド 19, セレニミド 20 およびセ レノニウムイリド 21 をそれぞれ立体保持で高收率高選 択的に得ることができた ${ }^{12,26,27)}$ 。光学活性セレノキシド およびセレノニウムイリドが安定な化合物であり, 室温 では全くラセミ化しない。それらの構造は X 線結晶構 造解析によって確認した。これに対し，セレニミドでは 
加水分解しやすいため, その構造を NMR 等で確認した が，その単離はできなかった ${ }^{28)}$

立体化学の結果から, 我々はこれらの反応についても dissociative な経路で進行しできたものと考えている。 また, 中間体と思われるセレンノニウムカチオンの単離 を試みたが, $\mathrm{X}$ 線結晶構造解析の結果から, セレンノニ ウムカチオンと対アニオンとが相互作用していることが 分かった ${ }^{29)}$ 。

\subsection{3. 光学活性ハロテルランの求核反応とその立体化} 学

光学活性テルルの有機化学は硫黄およびセレンに比べ ると,ごく最近まで非常に立ち遅れた分野であり，立体

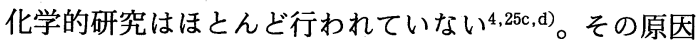
の 1 つは光学活性テルル化合物の合成法が確立されてい ないためである ${ }^{30)} 。$

これまでに, 光学活性テルル化合物の合成例として は，Lowry または Holliman らによって報告された図 6 に示す塩がある。彼らは，テルロニウム塩 22a または 22 b を合成しているすのの, その絶対構造については明ら かにしておらず，その光学純度については不明のままで ある ${ }^{31)}$ 。

最近, 上方らは, 不斉補助基または光学活性カラムを 用いて光学分割することにより, 光学活性テルロニウム 塩 22c やテルロキシド 22d の分離に成功し, その立体化 学については CD スペクトルやX X 線で明らかにした(図 $6)^{30)}$ 。

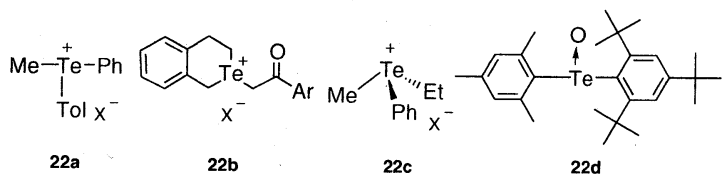

Fig. 6

我々はまず八ロテルランの反応性を調べるために, 光 学活性ハロテルランのハロゲン交換反応を行った ${ }^{32 \mathrm{a})}$ 。ア セトニトリル中, 八ロゲン化ナトリウム, 八ロゲン化銀 または八ロゲン化アンモニウムをハロテルランと反応さ せた結果, ナトリウム塩で八ロゲンが変換される場合と 銀塩またはアンモニウム塩でハロゲンが変換される場合 があり，中間体としてアルコキシテルロニウムイオンの 存在が示唆される(スキーム 10)。また，八ロテルラン間 での八ロゲン交換反応も観察された。同様なハロゲン化 ナトリウムやハロゲン化銀によるハロゲン交換反応は八 ロセレヌランからあ観察された ${ }^{12,27) 。}$

さらに, 我々は光学活性ハロテルランの反応を利用し

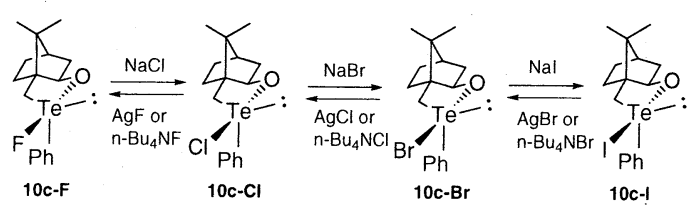

Scheme 10

て新たな光学活性テルロニウム化合物の合成ができるの ではないかと考え, 光学活性ハロテルランと有機リチウ ムまたは Grignard 試薬との反応を行った。その結果, 光学活性ハロオキサテルランから光学活性テルロニウム 塩を高ジアステレオ選択的に高收率で合成する事に成功 した $(ス キ ー ム 11)^{23,32 b) 。 ~}$

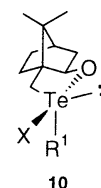

10

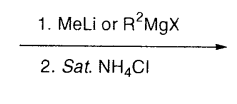

Scheme 11

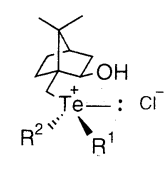

23
これらの塩の構造は化合物 $S_{\mathrm{Te}}$ および $R_{\mathrm{Te}}$-ボルニル エチルメチルテルロニウム塩の X 線結晶構造解析に よって確認できた(図 7) ${ }^{32 b) 。 ~}$

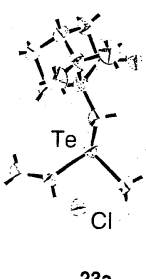

23a

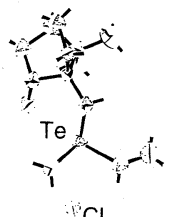

$\mathrm{Cl}$

23b
Fig.7 X-ray of 23a and 23b.

また，我々は今回見いだした反応を利用して有機合成 上有用な化合物である活性メチレンを持つ光学活性ベン ジルおよびアリルテルロニウム塩 ${ }^{33)}$ の合成にあ成功し た。その構造は $S_{\mathrm{Te}}$-ベンジルボルニルエチルテルロニウ ム塩の X 線結晶構造解析によって決定した ${ }^{23,32 b) 。 ~}$

得られた光学活性テルロニウム塩のテルル原子上の立 体化学について検討したところ，この反応は前述したよ うなハロスルフランや八ロセレヌランに対する求核反応 とは異なり, 立体反転で高選択的に進行していることが 分かった。この結果から, この反応では金属試薬の配位 による 4 員環遷移状態 Jを経由する associative な機構 と推定した (スキーム 12) ${ }^{32 \mathrm{~b})}$ 。 


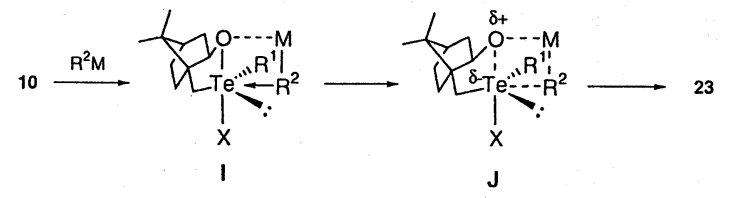

Scheme 12

しかし, 光学活性ハロテルランを用いて先述したハロ スルフランやセレヌランと同様な反応を行ったが，いず れの場合あ対応する光学活性テルル化合物は得られな かった。これは生成物が不安定であり, 分解したためと 考えられる ${ }^{25 \mathrm{c}, \mathrm{d})}$ 。

\section{2. 光学活性スピロスルフランの加水分解反応とその 立体化学}

我々はさらに, 同じ超原子価化合物であるスピロスル フランに対する求核反応の研究を行った。スピロスルフ ラン $14 \mathrm{c}, \mathrm{d}$ は含水 $\mathrm{EtOH}$ で再結晶したところ, スルホキ シド 24c，d がほぼ定量的に得られた。24c の立体化学に ついては X 線結晶構造解析によって確定し, 硫黄原子 上の絶対配置が $S_{\mathrm{S}}$ であることが分かった。一方, 14c，d をアルカリ条件下の加水分解反応するとスキーム 13 に 示すようなスルホキシド 25c, d を単一ジアステレオ マーとして高収率で得ることができた。25c，dのスペク トルデータから, その絶対配置と先程得られたスルホキ シド 24c,d と逆であることが分かった ${ }^{34)}$ 。

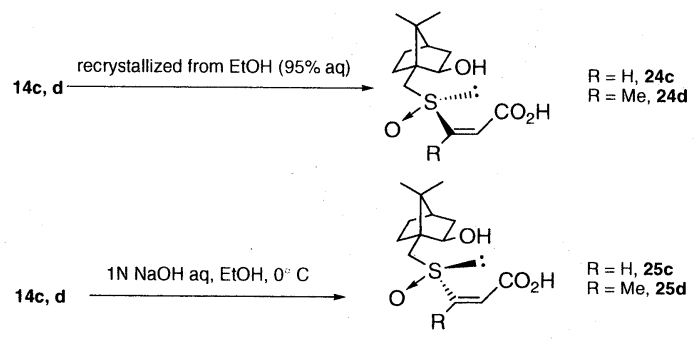

Scheme 13

そこで, 光学活性スピロスルフランの加水分解反応の 機構を解明するために, 我々はスピロスルフラン $14 \mathrm{a} を$ 用いて研究を行った ${ }^{19)}$ 。スピロスルフラン 14a は水に対 してある程度安定である。しかし, 我々は14a の加水分 解反応を検討したところ, 興味深い結果が得られた。す なわち，14a から酸性またはアルカリ性条件下加水分解 すると, 光学活性 $S_{\mathrm{S}}$ および $R_{\mathrm{S}}$ スルホキシド $24 \mathrm{a}, 25 \mathrm{a}$ が それぞれ単一ジアステレオマーとして得られた。24a， 25a の立体化学について X 線結晶構造解析により確認
した(スキーム 14)。また, スルホキシド 24a および 25a を用いて酸性またはアルカリ条件下の異性化実験を行っ た結果，24a および 25a はほとんど異性化しないことが 明らかになった。我々はこの加水分解反応では, 得られ た生成物の選択性は異性化した結果ではなく，スピロス ルフランの構造および反応条件によって得られたものと 考えられる。また，14a を ${ }^{17} \mathrm{O}$ または ${ }^{18} \mathrm{O} て ゙$ 標識した水を 用いて加水分解を行うことにより得られたスルホキシド の ${ }^{17} \mathrm{O}$ NMR および質量スペクトルの結果から， スルホ キシドの硫黄原子に結合した酸素原子が水分子に由来す ることも明らかにした ${ }^{19)}$ 。
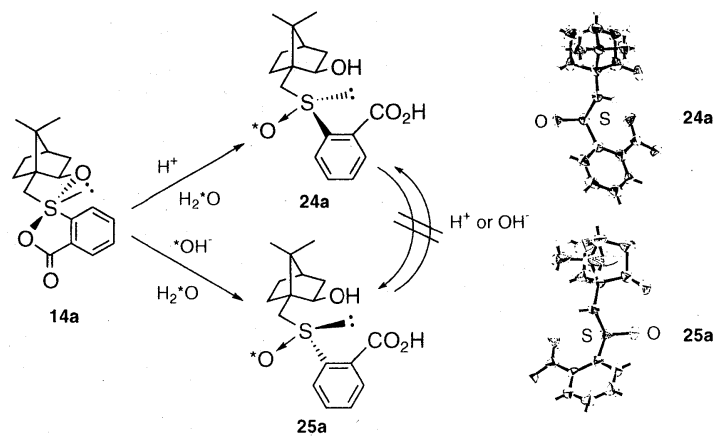

Scheme 14

以上の結果から, 我々はこの反応の立体化学はスピロ スルフランの両アピカル位の硫黄-酸素結合の反応性の 差異によって生じた結果と考えている。この反応は次に 示すような associative な機構を推定した。すなわち, 酸性条件下, 14a は六配位の硫黄化合物 $L$ を経由し，プ ロトン化された硫黄-酸素(アルコキシ)結合が優先的に 開裂することにより五配位の中間体 $\mathrm{M}$ になった後, 脱 プロトン化することにより硫黄原子上の絶対配置が $S_{\mathrm{S}}$ であるスルホキシド 24a が得られると考えられる(ス キーム 15)。

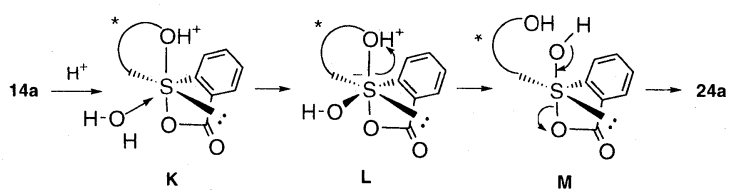

Scheme 15

アルカリ条件下, 六配位の硫黄化合物 $\mathrm{N}$ を経由し, 硫 黄-酸素(アシルオキシ)結合が硫黄-酸素(アルコキシ)結 合より切れやすいため, 硫黄-酸素(アシルオキシ)結合 が優先的に開裂することにより五配位の中間体 Oに 
なった後, 硫黄原子の絶対配置が $R_{\mathrm{S}}$ であるスルホキシ ド 25a が得られる(スキーム 16)。

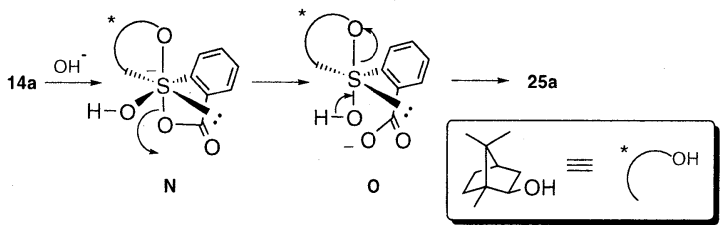

Scheme 16

また最近 Kapovits らはアキラルなスピロスルフラン の加水分解反応についての速度論的研究結果からは, dissociative な機構を強く支持している ${ }^{35)}$ 。この機構を 用いても，以上の反応結果を説明できる。すなわち，反 応条件によってスルフォニウムカチオン $\mathrm{P}$ およ゙ $\mathrm{Q}$ を 高選択的に生成するのがこれらの反応の重要なステップ であると考えられる(スキーム17)。
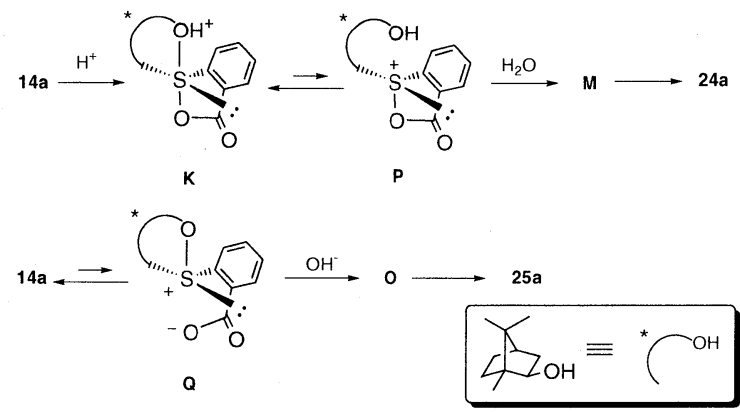

Scheme 17

以上の結果から，スピロスルフランの求核反応の立体 化学はアピカル位の結合および反応条件に強く影響され ると考えられる, これらの結果は今後へテロ原子上の不 斉構築法の開発に役立つと思われる。

\section{3. 光学活性カルコゲヌランの不斉反応への応用}

カルコゲヌランの生成および求核反応の高い選択性を 不斉反応に応用可能と考えて, セレン化合物を中心に， 光学活性カルコゲヌランを経由する光学活性アリルセレ ン化合物の $[2,3]$ シグマトロピー転位反応，または，エノ レートに対するハロセレヌランから生成した光学活性セ レノキシドを利用する不斉プロトン化反応等を行った。

\section{1. 光学活性アリルセレン化合物の不斉 $[2,3]$ シグマ トロピー転位}

セレン化合物の $[2,3]$ シグマトロピー転位反応は植村 ら数グループによって報告されている ${ }^{36)}$ 。セレン原子上
不斉中心が構築できれば, 転位反応により, セレン原子 上の置換基が側鎖の 3 位炭素に転位できる。高選択的に 転位できるためには，1)光学活性セレン化合物を高選択 的に生成する，2)効率良くセレン原子上の不斉中心から 転位するという条件が必要である。そこで, 我々は光学 活性セレン化合物の高選択的に合成する方法をすでに確 立し，また，ボルニル基のかさ高さを立体因子として利 用し, 高選択的に $[2,3]$ シグマトロピー転位が可能と考 えた。

3.1.1. 光学活性セレノキシドの不斉 $[2,3]$ シグマトロ ピー転位

E-アリルクロロセレヌラン 26( $\left.\mathrm{R}^{1}=\mathrm{alkyl}, \mathrm{R}^{2}=\mathrm{H}\right)$ を アルカリ加水分解したところ, 対応するアリルアルコー ル 30 が 26-32\% ee で得られ，Z-アリルクロロセレヌ ラン $26\left(\mathrm{R}^{1}=\mathrm{H}, \quad \mathrm{R}^{2}=\mathrm{alkyl}\right)$ のアルカリ加水分解では対 応するアリルアルコール 30 が $56-80 \%$ ee で得られた。 二置換のアリルクロロセレヌラン $26\left(\mathrm{R}^{1}=\mathrm{R}^{2}=\mathrm{alkyl}\right.$, $\left.\mathrm{R}^{1} \neq \mathrm{R}^{2}\right)$ の場合には, 対応するアルコール 30 が最高 $88 \%$ ee で得られた(スキーム18, 式 1$)$ 。この結果から 26 のアルカリ加水分解で生じたアリルセレノキシド 27 は, 容易に $[2,3]$ シグマトロピー転位を起こし, 転位の際 にセレン原子のキラリティーを炭素原子に転写すること が明らかになった。また得られたアリルアルコール 30 の絶対配置が, $E$ 体から得られたアルコールと $Z$ 体から 得られたものとでは逆の配置であったことから，E-アリ ルセレノキシドと Z-アリルセレノキシドは同じ endo 型 の遷移状態 $\mathrm{R}$ を経て進行していることが明らかになっ た

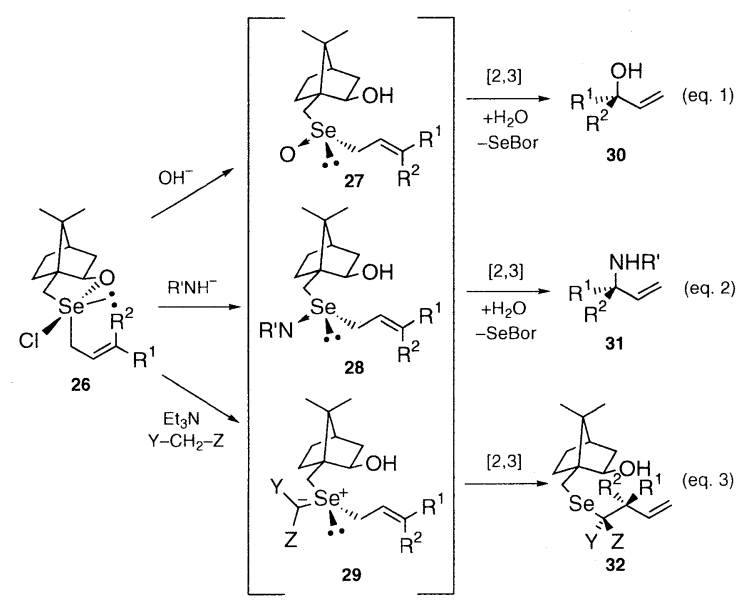

Scheme 18 
$R^{1} \overbrace{R^{2}}^{\substack{\text { Bor } \\ \text { Sue }}}$

R

$$
\mathrm{Nu}=\mathrm{O}, \mathrm{NR}^{\prime}, \mathrm{C}_{Z}^{\mathrm{Y}} \mathrm{Bor}=\mathrm{S}_{\mathrm{OH}}
$$

Fig. 8

\subsection{2. 光学活性セレニミドの不斉 $[2,3]$ シグマトロ} ピー転位

窒素求核剤として, LiNHTs と $\operatorname{LiNHP}(\mathrm{O}) \mathrm{Ph}_{2}$ を用い クロロセレヌラン $26\left(\mathrm{R}^{1}=i-\mathrm{Pr}, \mathrm{R}^{2}=\mathrm{H}\right)$ と反応させたと ころ, 対応するアリルアミド 31 が共に $93 \%$ ee で得られ た(スキーム 18, 式 2)。このことからクロロセレヌラン 26 に対する窒素求核剤の求核置換反応, および生じたセ レニミド 28 の $[2,3]$ シグマトロピー転位は共に高立体選 択的に進行しているあのと考えられる。窒素求核剤とし て LiNHCOOBn, LiNHCOOBu ${ }^{t}$ を用いた場合, 対応す るアリルアミド 31 の選択性がそれぞれ $67 \%$ ee, $73 \%$ ee と低下した。この結果はセレニミド 28 の $[2,3]$ シグマト ロピー転位の立体選択性が窒素上の置換基 $\left(\mathrm{R}^{\prime}\right)$ のか 高さによって左右されることを示している。また得られ たアリルアミド 31 の絶対配置から, セレニミド 28 の $[2,3]$ シグマトロピー転位は, セレノキシド 27 の転位と 同じ endo 遷移状態 R で反応が進行していることが明ら かになった

3.1.3. 光学活性セレノニゥムイリドの不斉 $[2,3]$ シグ マトロピー転位

クロロセレヌラン 28( $\mathrm{R}^{1}=$ alkyl, $\left.\mathrm{R}^{2}=\mathrm{H}\right)$ にトリエチ ルアミン存在下, フェニルスルホニルアセトニトリルを 反応させたところ, 生じたセレノニウムイリド 29 が高 立体選択的に $[2,3]$ シグマトロピー転位を起こし, 単一 の転位成績体 32 $\left(\mathrm{R}^{1}=\mathrm{alkyl}, \quad \mathrm{R}^{2}=\mathrm{H}, \quad \mathrm{Y}=\mathrm{CN}, \quad Z=\right.$ $\mathrm{SO}_{2} \mathrm{Ph}$ )を高収率で与えた(スキーム 18, 式 3)。また各種 の活性メチレン化合物を 26 と反応させたところ, 得ら れた転位成績体 32 の生成比がそれぞれの場合で異なっ ており, このことは 2 つの電子求引性置換基 $(\mathrm{Y}, \mathrm{Z})$ のか さ高さの差が，選択性を支配していることを示してい る。さらに,このようにして得られた転位成績体 32 の絶 対構造を決定したところ, セレノニウムイリド 29 の $[2,3]$ シグマトロピー転位はセレノキシド 27 やセレニミ ド 28 の転位と同様に endo 遷移状態 $\mathrm{R}$ を経由して反応 が進行していることが明らかになった ${ }^{39)}$ 。

3.2. 光学活性セレノキシドによる不斉プロトン化反応 エノラートを不斉プロトン化反応による光学活性カル ボニル化合物の合成に重要な方法として知られている。 そこで, 我々は安定な光学活性セレノキシドのボルニル
の水酸基を不斉プロトン源として不斉プロトン化反応を 行ない，(S)-34 が 64\% ee で得た(スキーム 19)。また, 反応系に臭化亜鉛を加えた場合, $89 \%$ ee で $(S)-34$ が得 られた ${ }^{40)}$ 。

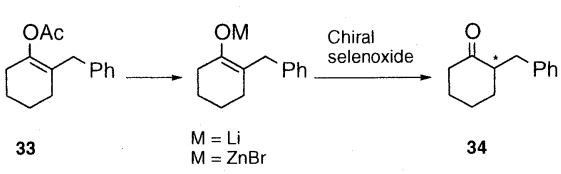

Scheme 19

\section{おわりに}

以上, 光学活性カルコゲヌランの合成とその求核反応 の立体化学について, 当研究室で最近明らかになった結 果を含めて述べた。これらの反応により光学活性カルコ ゲン化合物の不斉合成法を確立すると共に, 得られた光 学活性カルコゲン化合物を不斉反応に利用可能であるこ とが明らかになった。今後, 硫黄, セレン, テルル化合 物の反応性および反応機構の微妙な相違を速度論的検討 あ含めた研究に待つべきところあ多い。また，ここで述 ベたカルコゲヌランの反応機構がカルコゲン元素以外の 高周期典型宇素の反応によ゙のように適用できるか, どの 程度一般性があるかについて今後の発展を期待したい。

最後に, 本研究にご協力下さった研究室の諸氏(文献 記載)に厚くお礼申し上げます。本研究は文部省等の科 学研究費を受けて行われたもので, 文部省に深く感謝い たします。また，筆者の一人(張)は本稿をまとめるにあ たりご指導, ご助言を賜りました東京大学大学院総合文 化研究科友田修司教授に深く感謝いたしますとともに, 博士特別研究員としてご採用いただいた日本学術振興会 に深く感謝いたします。

（平成 11 年 2 月 15 日受理）

\section{文 献}

1）大饗茂, 有機硫黄化合物, 化学同人, 1982 等

2)（a）小泉徹, 有合化, 44, 576 (1986); (b) T. Koizumi, Phosphorus, Surfur and Silicon, 58, 111 (1991); (c) Y. Arai, T. Koizumi, Sulfur Reports, 15, 41 (1993)

3）（a）友田修司, 有合化，43，921 (1985); (b) C. Paulmier, "Selenium Reagents and Intermediates in Organic Synthesis", ed. by J.E. Baldwin, Pergamon Press, Oxford, N.Y. (1986); (c) 藤田 賢一，有合化，54，166 (1996);(d) K. Fujita， "Reviews on Heteroatom Chemistry", ed. by S. Oae, MYU, Tokyo, 16, 101 (1997);(e) T. 
Wirth, Liebigs Ann./Recueil, 1997, 2189

4) (a) N. Petragnani, "Tellurium in Organic Synthesis", Academic Press, London (1994); (b) L. Engman, Acc. Chem. Res., 18, 274 (1985); (c) N. Petragnani, J.V. Comasseto, Synthesis, 1986, 1 ;idem, ibid., 1991, 793, 897 ; (d) J.V. Comasseto, L.W. Ling, N. Petragnani, H.A. Stefani, ibid., 1997, 373 ; (e) 鈴木仁美, 有合化, 45, 603 (1987); (f) 植村栄, 有合化, 51, 804 (1993)

5) (a) A.J. Mancuso, D. Swern, Synthesis, 1981 , 164 ; (b) T.T. Tidwell, ibid., 1990, 857 ; (c) S. Oae, Y. Uchida, Acc. Chem. Res., 24, 202 (1991); (d) Y. Kita, Phosphorus, Sulfur and Silicon, 120 \& 121, 145 (1997);(e) T. Kawashima, R. Okazaki, Synlett, 1996, 600 ;(f) J. Jeske, W-W. du Mont, P.G. Jones, Angew. Chem., Int. Ed. Engl., 35, 2653 (1996); (g) M. Minoura, T. Sagami, K. Akiba, C. Modrakowski, A. Sudau, K. Seppelt, S. Wallenhauer, ibid. , 35, 2660 (1996)

6) (a) J C. Martin, I.C. Paul, Science, 191, 154 (1976); (b) J.C. Martin, ibid. , 221, 509 (1983); (c) R.A. Hayes, J.C. Martin, in "Organic Sulfur Chemistry, Theoretical and Experimental Advances", ed. by F. Bernardi, I.G. Csizmadia, A. Mangini, Elsevier, Amsterdam, (1985), p 408 ; (d) S. Oae, "Organic Sulfur Chemistry: Structure and Mechanism”, CRC Press, Boca Raton, FL, (1991); (e) 季刊化学総説, 有機 超原子価化合物, 日本化学会, 34, (1998)

7) (a) R.R. Holmes, Acc. Chem. Res., 5, 296 (1972);(b) idem, ibid., 12, 257 (1979); (c) C. Chuit, R.J.P. Corriu, C. Reye, J.C. Young, Chem. Rev., 93, 1371 (1993);(d) K.B. Dillon, ibid. , 94, 1441 (1994); (e) R.R. Holmes, Acc. Chem. Rev., 31, 535 (1998)

8) (a) T.M. Balthazor, J.C. Martin, J. Am. Chem. Soc., 97, 5634 (1975); (b) J.C. Martin, T.M. Balthazor, ibid. , 99, 152 (1977)

9) (a) M. Moriyama, T. Yoshimura, N. Furukawa, T. Numata, S. Oae, Tetrahedron, 32, 3003 (1976); (b) M. Matsugi, K. Hashimoto, M. Inai, N. Fukuda, T. Furuta, J. Minamikawa, S. Otsuka, Tetrahedron: Asymmetry, 6, 2991 (1995)

10) (a) Y.N. Yamakoshi, W.Y. Ge, K. Okayama, T. Takahashi, T. Koizumi, Heterocycles, 42, 129 (1996); (b) K. Nishide, Y. Shigeta, K. Obata, M. Node, J. Am. Chem. Soc., 118, 13103 (1996); (c) V.K. Aggarwal, J.G. Ford, S. Fonquerna, H. Adams, R.V.H. Jones, R. Fieldhouse, ibid., 120, 8328 (1998); (d) M.C.
Aversa, A. Barattucci, P. Bonaccorsi, P. Giannetto, M. Panzalorto, S. Rizzo, Tetrahedron: Asymmetry, 9, 1577 (1998); and references cited therein.

11) J. Zhang, T. Takahashi, T. Koizumi, Heterocycles, 44, 325 (1997)

12) T. Takahashi, N. Kurose, S. Kawanami, Y. Arai, T. Koizumi, M. Shiro, J. Org. Chem., 59, 3262 (1994)

13) T. Takahashi, J. Zhang, N. Kurose, S. Takahashi, T. Koizumi, M. Shiro, Tetrahedron: Asymmetry, 7, 2797 (1996)

14) J. Zhang, S. Saito, T. Takahashi, T. Koizumi, Heterocycles, 44, 575 (1997)

15) W.Y. Lam, E.N. Duesler, J.C. Martin, J. Am Chem. Soc. , 103, 127 (1981)

16) (a) H.J. Reich, J. Am. Chem. Soc., 95, 964 (1973); (b) L.J. Adzima, J.C. Martin, J. Org. Chem., 42, 4006 (1977); (c) R.S. Michalak, S R. Wilson, J.C. Martin, J. Am. Chem. Soc., 106, 7529 (1984); (d) Y. Takaguhci, N. Furukawa, Heteroatom Chem. , 6, 481 (1995); (e) Y. Takaguhci, N. Furukawa, Chem. Lett., 1996, 365 ; (f) idem, ibid. , 1996, 859

17) B. Lindgren, Acta. Chem. Scand., 26, 2560 (1972)

18) (a) P. Huszthy, I. Kapovits, Á Kucsman, L. Radics, Tetrahedron Lett., 1978, 1853;(b) S. Allenmark, S. Claeson, Tetrahedron: Asymmetry, 4, 2329 (1993); (c) J. Drabowicz, J.C. Martin, ibid. , 4, 297 (1993); (d) J. Drabowicz, J.C. Martin, Pure \& Appl. Chem., 68, 951 (1996); (e) D. Szabó, S. Szendeffy, I. Kapovits, Á. Kucsman, M. Czugler, A. Kámá, P. Nagy, Tetrahedron: Asymmetry, 8, 2411 (1997)

19) (a) J. Zhang, S. Saito, T. Koizumi, J. Am. Chem. Soc., 120, 1631 (1998); (b) idem, J. Org. Chem. , 63, 9375 (1998)

20) (a) I. Kapovits, J. Rábai, D. Szabó, K. Czakó, Á. Kucsman, G. Argay, V. Fülöp, A. Kálmán, T. Koritsászky, L. Párkányi, J. Chem. Soc., Perkin Trans. 2, 1993, 847 ; (b) S. F. Hornbuckle, P. Livant, T.R. Webb, J. Org. Chem. , 60, 4153 (1995); (c) D. Szabó, I. Kapovits, G. Argay, M. Czugler, A. Kálmán, T. Koritsászky, J. Chem. Soc., Perkin Trans. 2, 1997,1045

21) J. Zhang, S. Takahashi, S. Saito, T. Koizumi, Tetrahedron: Asymmetry, 9, 3303 (1998)

22）アキラルなカルコゲヌランの反応については, 以 下の総説と例がある：(a) 大饗茂, 化学総説, 日本 化学会, 学会出版センター, 47, 64 (1985); (b) 秋 葉欣哉, 山本陽介, 化学増刊, 化学同人, 115, 3 
(1988); (c) H. Fujihara, T. Uehara, N. Furukawa, J. Am. Chem. Soc., 117, 6388 (1995)

23) J. Zhang, S. Saito, T. Koizumi, Tetrahedron: Asymmetry, 8, 3357 (1997)

24) J. Zhang, S. Saito, T. Koizumi, J. Org. Chem., 63, 5265 (1998)

25) (a) T. Shimizu, M. Yoshida, M. Kobayashi, Bull. Chem. Soc., Jpn., 60, 1555 (1987); (b) T. Shimizu, M. Kobayashi, N. Kamigata, ibid., 61, 3761 (1988); (c) T. Shimizu, N. Kamigata, Org. Prep. Proced. Int. , 29, 605 (1997); (d) 清水 敏夫, 上方宣政, 有合化 , 55, 35 (1997)

26) T. Takahashi, N. Kurose, S. Kawanami, A. Nojiro, Y. Arai, T. Koizumi, M. Shiro, Chem. Lett., 1995, 379

27）黒瀬規之，博士論文 (富山医薬大，平成 8 年度)

28) H. Takada, M. Oda, Y. Miyake, K. Ohe, S. Uemura, Chem. Commun., 1998, 1557

29) S. Saito, J. Zhang, T. Koizumi, J. Org. Chem., 63, 6029, 10086 (1998)

30) (a) T. Shimizu, T. Urakubo, N. Kamigata, Chem. Lett., 1996, 297;(b) idem, J. Org. Chem., 62, 8032 (1997); (c) T. Shimizu, Y. Yamazaki, H. Taka, N. Kamigata, J. Am. Chem. Soc., 119, 5966 (1997); and references cited therein.

31) (a) T. M. Lowry, F.L. Gilbert, J. Chem. Soc. 1929, 2867 ; (b) F.G. Holliman, F.G. Mann, ibid., 1945, 37

32) (a) S. Takahashi, J. Zhang, S. Saito, T. Koizumi, Heterocycles, 46, 373 (1997); (b) J. Zhang, S. Saito, T. Koizumi, J. Org. Chem., 63, 5423 (1998)

33) (a) Y-Z. Huang, Y. Tang, Z-L. Zhou, Tetra- hedron, 54, 1667 (1998); (b) A-H. Li, L-X. Dai, V.K. Aggarwal, Chem. Rev., 97, 2341 (1997)

34）張健, 博士論文(富山医薬大, 平成 9 年度)

35) (a) E. Vass, F. Ruff, I. Kapovits, J. Rábai, D. Szabó, J. Chem. Soc., Perkin Trans. 2, 1993, 855 ; (b) E. Vass, F. Ruff, I. Kapovits, D. Szabó, Á Kucsman, J. Chem. Soc., Perkin Trans. 2, 1997, 2061; (c) T. Ádám, F. Ruff, I. Kapovits, D. Szabó, Á Kucsman, ibid., 1998, 1269

36) (a) J.N. Fitzner, R.G. Shea, J.E. Fankhauser, P. B. Hopkins, J. Org. Chem., 50, 419 (1985); (b) H.J. Reich, K.E. Yelm, ibid., 56, 5672 ; (1991); (c) F.A. Davis, T. Reddy, ibid., 57, 2559 (1992); (d) K. Komatsu, Y. Nishibayashi, S. Uemura, Tetrahedron Lett., 34, 2449 (1993); (e) Y. Nishibayashi, J.D. Singh, S. Fukuzawa, S. Uemura, J. Org. Chem., 60, 4114 (1995); (f) Y. Nishibayashi, T. Chiba, K. Ohe, S. Uemura, J. Chem. Soc., Chem. Commun., 1995, 1243; (g) Y. Nishibayashi, K. Ohe, S. Uemura, J. Chem. Soc., Chem. Commun., 1995, 1245

37) N. Kurose, T. Takahashi, T. Koizumi, J. Org. Chem., 61, 2932 (1996)

38) N. Kurose, T. Takahashi, T. Koizumi, J. Org. Chem., 62, 4562 (1997)

39) N. Kurose, T. Takahashi, T. Koizumi, Tetrahedron, 53, 12115 (1997)

40) (a) T. Takahashi, N. Nakao, T. Koizumi, Chem. Lett., 1996, 207 ; (b) idem, Tetrahedron: Asymmetry, 8, 3293 (1997) 